Boise State University

ScholarWorks

Management Faculty Publications and

Presentations

Department of Management

9-1-2014

\title{
The Relationship of HR Professionals' Online Experiences With Perceptions of Organizational Hiring and Promotion of Online Graduates
}

Gundars Egons Kaupins

Boise State University

James Edward Wanek

Boise State University

Malcolm Paulin Coco

Abilene Christian University 


\title{
Human Resource Professional Acceptance of Online Degrees
}

\author{
Wanek, James \\ Boise State University \\ jwanek@boisestate.edu \\ Kaupins, Gundars \\ Boise State University \\ gkaupins@boisestate.edu \\ Coco, Malcolm \\ Abilene Christian University \\ cocom@acu.edu
}

\begin{abstract}
Based on a survey of 264 human resource professionals from ten Society for Human Resource Management chapters in Texas, this study investigated how human resource professionals accept online degrees compared to degrees based on face-to-face coursework. If respondents were satisfied with their own online course experiences, they were most likely to view their organization as treating an online bachelor's or master's degree as equivalent to a face-to-face degree for hiring or promotion purposes. Having had online courses in the past or having completed an online degree had no similar and significant association with perceptions of online program equivalency.
\end{abstract}

Keywords: online education, face-to-face education, hiring, promotions, quality

Online degree programs have become more popular in the last ten years. Based on a survey of 2500 academic leaders, Allen and Seaman (2011) found that over 6.1 million students were taking at least one online course during the 2010 fall term. This is an increase from 1.6 million in 2002 and 2.4 million in 2006. About 31\% of higher education students take at least one online course. Whitaker (2012) reports that online enrollments in higher education increased ten percent last year whereas the overall growth in the higher education student population increased only one percent. Approximately $96 \%$ of colleges and universities offer online courses (Cater, Michel, \& Varela, 2012).

The growth of online programs has coincided with the growth of research on the quality of such programs. For example, a meta-analysis of ninety-nine studies published between 1996 and 2008 showed that students who participated in online programs performed at least equally to those in face-to-face settings (Means, Toyama, Murphy, Bakia, \& Jones, 2010). Other advantages of online learning include flexible scheduling and reduced travel expense (Gagne \& Shepherd, 2001) and general satisfaction with such learning (Campbell, Floyd, \& Sheridan, 2002). Some of the concerns with online degree programs involve the social isolation risk, increased potential for academic dishonesty, potential for information overload, limited computer access in some areas, inadequate computer equipment, and concerns about instruction quality (Waschull, 2001; Sapp \& Simon, 2005). Further concerns involve the use of false identities, loss of anonymity, and loss of confidentiality in online learning (AggerGupta, 2010).

\section{Purpose}

With the increasing online degree popularity and research on its efficacy, major questions involve how employers compare online programs to traditional face-to-face programs. Do employers view online programs as equivalent to face-to-face programs in terms of making hiring decisions? Do they view equivalency in terms of making promotion decisions? 


\section{Literature Review}

Online degrees have increasingly gained employer acceptance. A survey of Chief Learning Officers and Directors of Human Resources found that more than $62 \%$ had a favorable attitude toward online instruction and view online learning as the same or greater than regular classroom instruction (Hartman, 2007). Interviews with Wisconsin hiring managers found that half believed online MBA degrees were as valuable as campus-based MBA degrees (Bailey \& Flegle, 2012). Guendoo (2008) found that community college administrators were more willing to hire individuals who received their doctoral degrees online than administrators from traditional four year degree universities.

The Society for Human Resource Management (SHRM) surveyed 449 human resource professionals and found that if job applicants had identical job experiences and education, $39 \%$ responded that there was no difference between an online or traditional degree. About $41 \%$ responded with a preference for individuals who took both a bachelor's and a master's at a traditional program. (SHRM, 2010). An earlier SHRM (2009) survey of 570 human resource managers found that $47 \%$ either agreed or strongly agreed that online university programs are equally credible to traditional degree programs.

A one-on-one comparison between traditional and online preferences yields different results. In a national survey of 159 health care administrators, 95\% of respondents would hire someone from a traditional degree program rather than an online program when given the choice (Adams, DeFleur, \& Heald, 2007). In a study of 270 small and medium-size companies, $96 \%$ of managers said they would select traditional job candidates over those with online degrees and 75\% would select traditional over those with hybrid degrees (Adams \& DeFleur, 2006).

A survey of Certified Public Accounting recruiters did not perceive a difference between a candidate who received an online Masters of Accounting degree versus a traditional accounting degree (Metrejean \& Noland, 2011). In contrast, Kohlmeyer, Seese, and Sincich (2011) found that there was a strong preference among recruiters to hire students who completed face-to-face programs. Reasons for the bias against online programs include the lack of interpersonal experiences, weak reputation and quality of online programs, professors did not know their online students, lack of rigor, and lack of familiarity with online instruction.

In general, the literature shows that online degrees are showing increasing acceptability in terms of hiring. However, they are not as acceptable yet as traditional degree programs.

The literature is missing several dimensions of acceptability. While there is considerable literature comparing online to face-to-face graduates concerning hiring, there is scant research on promotions of graduates of online programs compared to graduates of face-to-face programs.

The literature is also missing more detailed analysis of respondent characteristics. For example, the comprehensive SHRM $(2009,2010)$ surveys reported basic online education opinions of human resource managers but did not go into any depth concerning the demographic characteristics of the human resource managers and the effects these demographic characteristics have on the results. Sample demographic characteristics include whether respondents have taken online courses, have graduated from the online courses, and were satisfied with the online courses. Kohlmeyer, Sees and Sincich (2011) suggested that the lack of familiarity with online instruction was associated with a lower impression of online accountancy programs compared to face-to-face programs.

\section{Hypotheses}

Given that past research has been missing several measures of online program acceptability especially regarding the promotion of online graduates, the following hypotheses are made.

Prior Experience Hypotheses:

A person's prior experience with an online degree program will be associated with the person perceiving their organization to treat an online degree as equivalent to a traditional college or university program when making a hiring or promotion decision. 
Personal Satisfaction Hypotheses:

A person's satisfaction with online degree classes will be associated with perceiving their organization to treat an online degree as being equivalent to a traditional college or university degree program when making a hiring or promotion decision.

Graduation Hypotheses:

A person's graduation from an online degree program will be associated with perceiving their organization to treat an online degree as being equivalent to a traditional college or university program when making a hiring or promotion decision.

These hypotheses are important to help expand the research concerning online education because it shows what effect prior experience with online education has on perceptions of organization policies associated with online programs. It also shows how online education is perceived in the context of hiring and promotion decisions.

\section{Methodology}

\section{Data Collection}

Human resource managers, specialists, consultants, and other human resource professionals were the target sample. These professionals tend to have significant knowledge of organizational policies associated with training (DeCenzo \& Robbins, 2010).

To obtain the target sample, one co-author attended ten Society for Human Resource Management (SHRM) monthly meetings and asked attendees to complete a two page questionnaire covering the key issues associated with the hypotheses. At these meetings, 264 respondents completed the survey between February and April of 2012.

Questionnaires were distributed in San Antonio, Grand Prairie, Fort Worth, Lubbock, Brownwood, New Braunfels, Abilene, Wichita Falls, Amarillo, and Stephenville, Texas. The chapters were from large cities such as San Antonio (population 1,327,407) and Fort Worth $(1,197,816)$ and smaller towns such as Brownwood $(19,288)$ and Stephenville $(17,123)$ (Texas State Library and Archives Commission, 2010).

\section{Sample}

As shown on Table 1, most respondents are human resource managers and are involved in hiring. About two-thirds work in companies that have 500 or fewer employees. Almost half are with companies that are in multiple locations.

\section{Results}

Results from Table 2 show that the majority (51\%) of respondents believe that when making a hiring decision that requires a degree, their organization treats an online bachelor's degree as equivalent to a similar degree from a traditional college or university. About $15 \%$ stated it has a lesser value and about $28 \%$ provided a conditional response of acceptability dependent upon the job opening. The results for the hiring decisions related to the online master's degree appeared similar to the results for the online bachelor's degree involving whether the master's degree was equivalent or of lesser value to a traditional program and whether a master's degree was acceptable dependent on the job opening.

When making promotion decisions, about $72 \%$ of respondents believe that their organization treats an online degree as equivalent to a similar degree from a traditional college or university. Only about $12 \%$ viewed the online degree of lesser value.

When making a one-on-one contrast between online degrees and traditional college programs, the results show major differences in perceptions. When asked if an online degree would be considered equivalent to a degree from a traditional college or university, only about $18 \%$ of respondents agreed that there would be equivalence if the online 
This is an author-produced, peer-reviewed version of this article. The final, definitive version of this document can be found online at Journal of Education for Business, published by Taylor and Francis. Copyright restrictions may apply. doi: 10.1080/08832323.2013.852076

degree was earned less than three years ago. The percentage jumps to about $74 \%$ if there is significant work experience, $45 \%$ if there are hard-to-find skills, and $58 \%$ if there are other relevant licenses or professional credentials.

Table 3 shows correlation results between key questions in the survey from Table 2 and various demographic questions from Table 1 . The most significant results were the strong positive association between respondent satisfaction with online classes they have taken and their perception of how their organization views an online degree as equivalent to traditional degrees. The correlations were significant $(\mathrm{p}<.01)$ for bachelor's degree hiring decisions, master's degree hiring decisions and general promotion decisions associated with colleges and universities.

The Prior Experience Hypotheses were not confirmed. A person's prior experience with an online degree program was not associated with the person perceiving his or her organization to treat an online degree as equivalent to a traditional college or university program when making a hiring or promotion decision. Table 3 shows no significant correlations between having taken an online course and any hiring decision variables for bachelor's degrees or master's degrees. Table 4 shows no significant correlations between having taken an online course and the two promotion decision variables.

The Personal Satisfaction Hypotheses were confirmed for hiring and promotions but not for reimbursement. In other words, a person's satisfaction with online degree classes was associated with perceiving his or her organization to treat an online degree as being equivalent to a traditional college or university degree program when making a hiring and promotion decision but not a reimbursement decision. Table 3 shows significant correlations $(\mathrm{p}<.01)$ between being satisfied with online courses and any hiring decision variables for bachelor's degrees. Two of the three correlations are significant for master's degrees. Table 4 shows significant correlations $(p<.01)$ between being satisfied with online courses and promotion decisions.

The Graduation Hypotheses were not confirmed. In other words, a person's graduation from an online degree program was not associated with perceiving his or her organization to treat an online degree as being equivalent to a traditional college or university program when making a hiring, promotion, or reimbursement decision. The tables showed no significant correlations between having completed an online degree and any hiring (Table 3) or promotion (Table 4) decisions.

Variables such as "make hiring decisions for your organization," "work in a single location," "work in multiple locations," and "work as an HR manager or director" were not significantly related to the hiring or promotion decision variables.

\section{Discussion}

Based on the literature review and the survey results, online education is still not perceived as equivalent to traditional education in colleges and universities. Only about half of the respondents in the human resource field believed that their organizations treat online graduates as equivalent to traditional program graduates for hiring purposes.

The unique contribution of this paper, however, concerns what factors influence respondents' perceptions of how their organizations view online education compared to face-to-face education in terms of hiring and promotion decisions. Apparently, respondents' prior experience with online courses and their prior completion of an online degree were not associated with their perception that their organization treats an online bachelor's or master's degree as equivalent to traditional programs for hiring purposes. In contrast, their satisfaction with online classes had strong correlations with their perception that their organization treats online equivalent to traditional.

There are several interpretations of the result focusing on the influence of satisfaction with the online environment. It is possible that bad personal experiences with the online environment may negatively cloud respondent perceptions so they perceive their organizations as being negative toward online programs. It is possible that bad personal experiences with the online environment may allow respondents to personally influence the hiring practices 
This is an author-produced, peer-reviewed version of this article. The final, definitive version of this document can be found online at Journal of Education for Business, published by Taylor and Francis. Copyright restrictions may apply. doi: 10.1080/08832323.2013.852076

of their companies. This can be done through direct leadership roles as HR managers or directors (most of the respondents had these roles) or through indirect influence by convincing those who have influence such as HR managers and hiring directors that online programs are not worth much.

\section{Implications for Practitioners}

Survey results show that there is close to a fifty-fifty split between human resource practitioners on whether online degrees are equivalent to face-to-face degrees. Individuals with online degrees are still facing a perceptual uphill battle when it comes to hiring and promotion decisions in companies.

A major factor that may influence hiring and promotion decisions is whether human resource practitioners have had satisfaction with their online education. If a company hired human resource managers who have had poor experiences with their online education, it appears likely that these individuals would perceive their organizations as not promoting many individuals who have had online degrees.

\section{Future Research}

Hiring and promotions are basic human resource-related decisions made by organizations that are partly based on information about the candidate's educational background. These are by far not the only decisions. Whether an employee has participated in online or face-to-face education can affect many other human resource-related decisions including the initial pay and benefits, potential raises, employee discipline, selection for future training programs, and performance appraisals.

Future research needs to analyze different types of online programs in more detail. The present research looked at accreditation standards and found few significant correlations. However, future research can look at what respondents think about specific online programs (e.g., University of Phoenix) compared to various online programs offered by traditional universities. According to Webley (2012), perhaps a significant reason why people might not get a job from an online degree program is they got the degree from a for-profit entity rather than a degree using the online medium. The entity is more important than the medium. Prestigious universities sponsoring Massive Open Online Courses, or MOOCs such as Harvard, MIT, Stanford and Princeton might increase the interest of students by employers who complete those courses. Hybrid course programs that combine online and face-to-face elements taught by traditional universities also need to be investigated for their acceptability.

Future research also can look at the motivation of respondents taking online classes. It is possible that those taking online classes due to necessity due to money or scheduling reasons might have a higher respect for online programs. Those taking online classes just for fun might not have much respect for the classes.

\section{Summary}

The most significant result of the study was the significant correlation between respondent satisfaction with their online course experiences and the belief that their organization treated and online bachelor's or master's degree as equivalent to a face-to-face degree for hiring or promotion purposes. Past online courses or completion of online degrees had no significant association with respondent opinions of online program equivalency with face-to-face programs for hiring or promotion purposes. 
This is an author-produced, peer-reviewed version of this article. The final, definitive version of this document can be found online at Journal of Education for Business, published by Taylor and Francis. Copyright restrictions may apply. doi: 10.1080/08832323.2013.852076

TABLE 1

Demographic Characteristics

Demographic Topics $\quad \% \quad \mathrm{~N}$

Have taken courses online

Yes $\quad 45.7 \quad 121$

No $\quad 53.2 \quad 141$

Satisfied with online classes compared to traditional classes

18.148

Satisfied

$17.7 \quad 47$

Neither satisfied nor dissatisfied

$7.2 \quad 19$

Dissatisfied

Very dissatisfied

$2.6 \quad 7$

$0.0 \quad 0$

Have completed an online degree

Yes

$5.3 \quad 14$

No

$93.6 \quad 248$

Make hiring decisions for your organization

Yes

$70.6 \quad 187$

No

$27.5 \quad 73$

Number of employees at your business location

1-100 employees

$30.3 \quad 79$

101-500 employees

$36.8 \quad 96$

501-1000 employees

$11.1 \quad 29$

1001-2000 employees

$9.6 \quad 25$

2001 + employees

$11.9 \quad 31$

Approximate business structure

Single location

35.593

Multiple locations

$46.2 \quad 121$

Division of a national entity

$17.9 \quad 47$

Other

$1.9 \quad 5$

Job Title

Human resources manager/director/vice president

$47.7 \quad 125$

Human resource specialist

$22.2 \quad 58$

Other

$33.2 \quad 87$

SHRM Chapter Location

San Antonio

Grand Prairie

19.351

Fort Worth

$7.2 \quad 19$

Lubbock

15.240

Brownwood

$9.8 \quad 26$

New Braunfels

$3.0 \quad 8$

Abilene

$5.7 \quad 15$

Wichita Falls

$12.5 \quad 33$

Amarillo

$12.1 \quad 32$

Stephenville

$10.2 \quad 27$

$4.9 \quad 13$ 
This is an author-produced, peer-reviewed version of this article. The final, definitive version of this document can be found online at

Journal of Education for Business, published by Taylor and Francis. Copyright restrictions may apply. doi: 10.1080/08832323.2013.852076

TABLE 2

Use of College Degrees in Hiring and Promotion Decisions

\begin{tabular}{lll}
\hline Questions & $\mathrm{N}$
\end{tabular}

1 When making a hiring decision that requires a degree, my organization treats an online bachelor's degree... as equivalent to a similar degree from a traditional college or university $\quad 51.0 \quad 134$

as of lesser value than a similar degree from a traditional college or university $\quad 15.2 \quad 40$

as acceptable but it depends on the job opening $\quad 28.1 \quad 74$ as insufficient to meet hiring standards $\quad 1.5 \quad 4$ don’t know $\quad 10.3 \quad 27$

2 When making a hiring decision that requires a degree, my organization treats an online master's degree...

as equivalent to a similar degree from a traditional college or university $\quad 50.8 \quad 133$

as of lesser value than a similar degree from a traditional college or university $\quad 15.6 \quad 41$

as acceptable but it depends on the job opening $\quad 28.1 \quad 62$

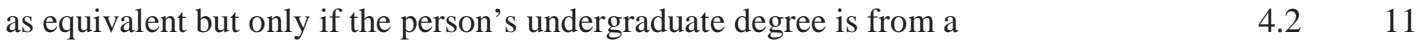

traditional college or university

as insufficient to meet promotion qualifications $\quad 0.8 \quad 2$

don't know $\quad \begin{array}{ll}12.2 & 32\end{array}$

3 When making a promotion decision that requires a degree, my organization treats

an online degree...

as equivalent to a similar degree from a traditional college or university $\quad 71.8 \quad 183$

as of lesser value than a similar degree from a traditional college or university $\quad 11.8 \quad 30$

as insufficient to meet promotion qualifications $1.2 \quad 3$

don’t know $\quad 16.1 \quad 41$

4 In my organization, an online degree would be considered equivalent to a degree from a traditional college or university if the candidate...

earned the online degree less than three years ago $\quad 17.734$

has significant work experience $\quad 74.2 \quad 139$

has hard-to-find skills $\quad 45.3 \quad 87$

has other relevant licenses or professional credentials (e.g. PHR, CPA) $\quad 58.3112$ 
TABLE 3

\section{Correlation Results for Hiring Decisions}

\begin{tabular}{|c|c|c|c|c|c|c|c|c|}
\hline $\begin{array}{c}\text { Hiring } \\
\text { Decisions }\end{array}$ & 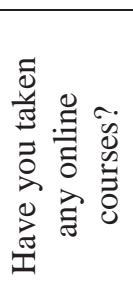 & 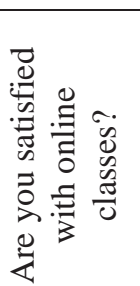 & 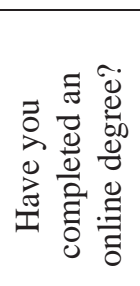 & 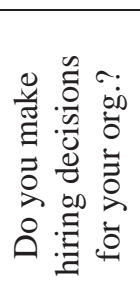 & 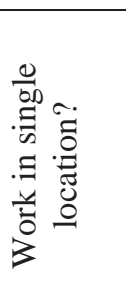 & 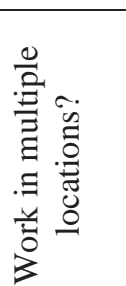 & 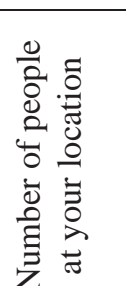 & 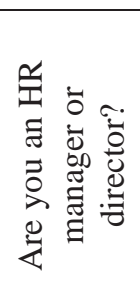 \\
\hline \multicolumn{9}{|c|}{$\begin{array}{c}\text { When making a hiring decision that requires a degree, my organization treats an online bachelor's degree as.... to } \\
\text { a similar degree from a traditional college or university. }\end{array}$} \\
\hline equivalent & -.095 & $.363 * *$ & .097 & .042 & .042 & -.002 & .019 & -.040 \\
\hline lesser & -.072 & $-.225 * *$ & -.054 & .003 & -.050 & .013 & -.087 & .015 \\
\hline acceptable & .042 & $-.217 * *$ & -.073 & $.197 * *$ & .000 & -.027 & -.002 & $.214^{* *}$ \\
\hline \multicolumn{9}{|c|}{$\begin{array}{c}\text { When making a hiring decision that requires a degree, my organization treats an online master's degree as... to a } \\
\text { similar degree from a traditional college or university. }\end{array}$} \\
\hline equivalent & -.091 & $.344^{* *}$ & .099 & .074 & -.044 & .017 & -.097 & .018 \\
\hline lesser & -.062 & $-.334 * *$ & -.056 & .058 & $\begin{array}{l}.011 \\
\end{array}$ & .044 & -.049 & .092 \\
\hline acceptable & .015 & -.014 & -.052 & $.143^{*}$ & -.030 & .070 & -.051 & $.123^{*}$ \\
\hline
\end{tabular}

${ }^{*} \mathrm{p}<. .-05 ;{ }^{* *} \mathrm{p}<.01$

TABLE 4

Correlation Results for Promotion Decisions

\begin{tabular}{|c|c|c|c|c|c|c|c|c|}
\hline $\begin{array}{c}\text { Promotion } \\
\text { Decisions }\end{array}$ & 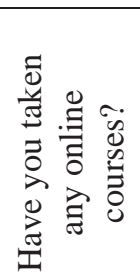 & 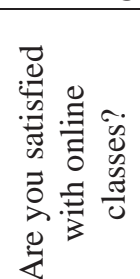 & 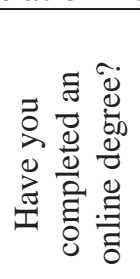 & 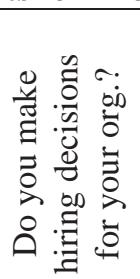 & 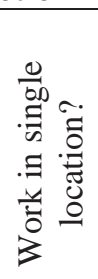 & 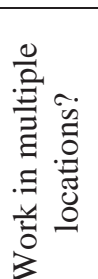 & 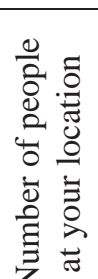 & 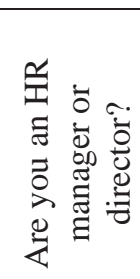 \\
\hline
\end{tabular}

When making a promotion decision that requires a degree, my organization treats an online degree as... to a similar degree from a traditional college or university.

\begin{tabular}{|c|c|c|c|c|c|c|c|c|}
\hline equivalent & -.013 & $.282^{* *}$ & .113 & .221 & -.006 & .108 & .014 & $.250 * *$ \\
\hline lesser & .045 & $-.286 * *$ & -.087 & .089 & -.080 & .062 & .003 & -.032 \\
\hline
\end{tabular}

In my organization, an online degree would be considered equivalent to a degree from a traditional college or university if the candidate.....

\begin{tabular}{|c|c|c|c|c|c|c|c|c|}
\hline $\begin{array}{c}\text { has online } \\
\text { degree }<3 \\
\text { years ago }\end{array}$ & .037 & $.162^{*}$ & .074 & .122 & .016 & -.004 & -.112 & .044 \\
\hline $\begin{array}{c}\text { has } \\
\text { significant } \\
\text { work } \\
\text { experience }\end{array}$ & $.186^{*}$ & .077 & -.011 & $.210^{* *}$ & -.122 & .096 & .066 & $.141^{*}$ \\
\hline $\begin{array}{c}\text { has hard- } \\
\text { to-find } \\
\text { skills }\end{array}$ & -.002 & .015 & $-.167^{*}$ & -.014 & .001 & -.038 & .006 & -.105 \\
\hline $\begin{array}{c}\text { has other } \\
\text { redentials }\end{array}$ & .078 & .003 & .008 & $-.254^{* *}$ & .113 & .018 & -.140 & $-.263^{* *}$ \\
\hline
\end{tabular}

${ }^{*} \mathrm{p}<.-.05 ; * * \mathrm{p}<.01$ 


\section{References}

Adams, J. \& DeFleur, M. H. (2006). The acceptability of online degrees earned as a credential for obtaining employment. Communication Education, 55, 32-45.

Adams, J., DeFleur, M. H., \& Heald, G. R. (2007). The acceptability of credentials earned online for obtaining employment in the health care professions. Communication Education, 56, 292-307.

Agger-Gupta, D. (2010) Exploring ethical dimensions of online learning. In K Rudestam \& J. Schoenholtz-Read Handbook of Online Learning, ( $2^{\text {nd }}$ ed.), Thousand Oaks, CA: Sage.

Allen, I. E. \& Seaman, J. (2011). Going the Distance: Online Education in the United States. Accessed November 30, 2012 from http://sloanconsortium.org/publications/survey/going distance_2011.

Bailey, J. S. \& Flegle, L. V. (2012). Hiring managers’ perceptions of the value of an online MBA. Online Journal of Distance Learning Administration, 15, Accessed November 30, 2012 from http://www.westga.edu/ distance/ojdla/summer152/bailey_flegle152.html.

Campbell, M. C., Floyd, J. \& Sheridan, J. B. (2002). Assessment of student performance and attitudes for courses taught online versus onsite. Journal of Applied Business Research, 18, 45-51.

Cater, J. J., Michel, N, \& Varela, O. E. (2012). Challenges of online learning in management education: an empirical study. The Journal of Applied Management and Entrepreneurship, 17, 76-96.

DeCenzo, D. A. \& Robbins, S. P. (2010). Fundamentals of Human Resource Management. (10 ${ }^{\text {th }}$ ed.), Hoboken, N. J.: John Wiley.

Gagne, M. \& Shepherd, M. (2001). Distance learning in accounting. T. H. E. Journal, 28, 2-12.

Guendoo, L. (2008). Community colleges friendlier to online Ph.Ds. Online Journal of Distance Learning Administration, 11, Retrieved December 18, 2012 from http://www.westga.edu/ distance/ojdla/fall113/guendoo113.html.

Hartman, K. E. (2007). Major employers embrace online degrees. Distance Learning Today. 1, 1, $13-15$.

Kohlmeyer, J. M., Seese, L. P. \& Sincich, T. (2011). Online versus traditional accounting degrees: perceptions of public accounting professionals, In Anthony H. Catanach, Dorothy Feldmann (eds.) Advances in Accoutning Education: Teaching and Curriculum Innovations, 12, 139-165.

Means, B, Toyama, Y, Murphy, R, Bakia, M \& Jones, K. (2010). Evaluation of evidence-based practices of online learning: a meta-analysis and review of online learning studies. U. S. Department of education Office of Planning, evaluation, and Policy Development Policy and Program Studies Service, 1-66.

Metrejean, E. \& Noland, T. (2011). An analysis of CPA firm recruiters' perceptions of online Masters of Accounting degrees. Journal of Education for Business, 86, 25-30.

Sapp, D. A. \& Simon, J. (2005). Comparing grades in online and face-to-face writing courses: interpersonal accountability and institutional commitment. Computers and Composition, 22, 471-489.

Society for Human Resource Management (2009). SHRM Poll: Credibility of Online Degrees. Accessed November 30, 2012 from http://www.shrm.org/research/surveyfindings/articles/pages/credibilityofonlinedegrees.aspx.

Society for Human Resource Management (2010). SHRM Poll: Hiring Practices and Attitudes: Traditional vs. Online Degree Credentials. Accessed November 30, 2012 from http://www.shrm.org/research/surveyfindings/articles/pages/hiringpracticesandattitudes.aspx.

Texas State Library and Archives Commission. (2010). 2010 Census: Population of Texas Cities Arranged in Descending Order. Accessed December 4, 2012 from https://www.tsl.state.tx.us/ref/abouttx/popcity32010.html.

Waschull, S. B. (2001). The online delivery of psychology courses: attrition, performance, and evaluation. Computers in Teaching, 28, 143-147.

Webley, K. (2012, Oct. 18). Can an online degree really help you get a job? Accessed January 11, 2013 from http://nation.time.com/2012/10/18/can-an-online-degree-really-help-you-get-a-job/.

Whitaker, A. (2012). Are online MBA degrees worth it compared to traditional MBAs? Accessed November 30, 2012 from http://www.deseretnews.com/article/865554922/Are-online-MBA-degrees-worth-it-comparedto-traditional-MBAs.html?pg=all. 